\title{
Charities fight back
}

\section{London}

BRITAIN's leading medical research charities have decided to take a more active role in the ongoing animal welfare debate. The newly formed Research for Health Charities Group (RHCG), which aims to explain the need for continued use of animals in medical research, is in part a response to two tactics employed by animal rights groups in recent years: a highly successful campaign aimed at schoolchildren, and the attempt to dissuade supporters from donating to charities that fund research using animals.

Myc Riggulsford, who heads the new group, says he intends not only to illustrate the importance of the medical charities' animal-based research, but also to put this work in perspective. The eight charities backing RHCG (which include the 'big three' — the Wellcome Trust, the Imperial Cancer Research Fund and the Cancer Research Campaign) fund a total of more than $£ 200$ million of medical research each year - more than the government-funded Medical Research Council - but only $£ 10$ million of that is spent on animal research. Riggulsford says that animal rights groups have consistently misrepresented this fact. "We are no longer prepared to let the extremists go unanswered."

Riggulsford dismisses the claim of animal rights groups that medical research could progress solely by using tissue culture and other alternatives to animal experiments. He also points out that most charities that claim to fund no animal research still depend on animals to some degree. Big $\mathrm{C}$, for example, supports research on cell cultures that grow in a medium containing fetal calf serum - an animal product.

The charities' move is the latest in a series of moves by the British research community to counter the perceived success of animal rights campaigners, who have made a point of targeting young people. Last year, for example, a number of scientific and medical societies, led by the British Association, issued a declaration supporting the continued use of animals in research (see Nature 346, 782; 1990). But the new group may have a greater effect, as the medical research charities have a higher profile than most scientific bodies and command greater public support.

Given the activity of groups such as Animal Aid and the British Union for the Abolition of Vivisection in British schools, Riggulsford expects RHCG to focus much of its attention initially on schoolchildren and their teachers, perhaps by offering to provide speakers. The group's supporters would like to see RHCG leading the debate on animal experimentation. "Hitherto, we've just responded to overt or implied criticism from animal rights groups or the media," says Nick Wright, director of clinical research at the Imperial Cancer Research Fund. "We need to be proactive." $\quad$ Peter Aldhous

\section{New base for South Africa}

\section{Cape Town}

SOUTH Africa is to embark on major expansion of its Antarctic programme, including the building of a new research station, SANAE 4, and the refurbishment of its polar supply ship, the SA Agulhas, to improve its oceanographic research facilities.

The site earmarked for the new base is an inland rock outcrop (nunatak) named Vesleskarvet in the Norwegian sector, about $200 \mathrm{~km}$ south of the existing base, SANAE 3 , which has reached the end of its lifetime. An environmental impact assessment will be carried out this austral summer, and the base is to be constructed during the 1992-93 season. The new base has been designed to accommodate 80 people during the summer, and a team of 17 to overwinter on the ice.

According to the chairman of the South African Committee for Antarctic Research, Professor Brian Huntley, SANAE 4 will make possible a new research programme on the terrestrial ecology of nunataks. South African research programmes on terrestrial ecology have so far been largely confined to those conducted on Marion and Prince Edward islands, as SANAE 3 has very limited facilities for biological research.

In addition, the new station will provide vastly superior facilities for the atmospheric physics programme, which is concerned with cosmic rays, stratospheric ozone, and magnetospheric phenomena which are observed at relatively high latitudes.

The refurbishment of the SAAgulhas is expected to cost about R20 million ( $\$ 7$ million) and will begin in April. It will improve facilities for biological, hydrological and geological sampling. These facilities will make possible an enhanced contribution by South Africa to global research programmes on carbon flux and heat flux, in which the Southern Ocean has been identified as a key area.

Apart from the capital expenditure on the new base and refurbishing the SA Agulhas, approximately R13 million will be spent annually on running the Antarctic programme for the next five years. This makes Antarctic research very well-funded in South African terms. Michael Cherry

\section{A sad state of affairs}

\section{São Paulo}

A gROUP of prominent Brazilian scientists is predicting "imminent collapse" of work at universities and research institutions in Brazil because the budget for science and technology "is not being honoured by the federal government". This funding shortfall is not an unusual situation, and each time it happens scientists complain that things are getting worse and worse, so the Brazilian public has learned to turn a deaf ear to these complaints. But this time the scientists may not be crying wolf.

A manifesto describing the situation has been issued by 105 scientists, all of them members of the advisory committee of the National Council for Development of Science and Technology, the main funding agency. The members were elected to the committee by the scientific community, so they are fairly well representative of working scientists.

The manifesto says that 2,316 research projects approved by the committee did not receive any money this year. It adds that even though the year is near its end, only half the budget of another funding agency, the Agency for Financing Studies and Projects, has been delivered. And even if fully funded, that agency's budget amounts to only $\$ 26$ million.

Furthermore, the biggest internationally funded programme is paralysed. The World Bank has offered $\$ 150$ million to the Programme for the Support of Scientific and Technological Development, but the bank can make the loan available only if the Brazilian government matches it. "This has not yet happened," the manifesto says. Ricardo Bonalume

\section{Physicist jumping ship}

\section{São Paulo}

BRAZIL's pre-eminent physicist, José Leite Lopes, has said he will be leaving the country to return to the University of Strasbourg in France, where he worked in the 1970s during a forced exile while Brazil was in the hands of a military regime. In an angry newspaper interview, he said he is fed up and "disappointed with the whole country" because of such things as rampant corruption, lack of education and children dying of hunger. "I never thought in my youth that we would arrive at this situation, when the country is quickly walking towards the last place in the Third World," he said.

In the late 1940s, full of hope for physics research in Brazil, he founded the Brazilian Centre for Research in Physics with Cesar Lattes, who discovered pion decay in a cosmic ray observatory in the Bolivian Andes. Asked if he intends to return eventually to Brazil, Leite Lopes said he would, at least to visit relatives. "To work, I don't know."
Ricardo Bonalume 